\title{
Maspin and GLUT-1 Expression in Endometrial Carcinomas and Prognostic Relevance
}

\section{Endometriyum Kanserinde Maspin ve GLUT-1 Ekspresyonu ve Prognoz İlişkisi}

\author{
Sadık Sözdinler' ${ }^{1}$ Mehmet Musa Aslan', Ahmet Yanar², Erkan Çağlıyan, \\ Meral Koyuncuoğlu², Uğur Saygılı ${ }^{2}$ \\ ${ }^{1}$ Muş Devlet Hastanesi, Kadın Hastalıkları Ve Doğum Kliniği, Muş \\ ${ }^{2}$ Dokuz Eylül Üniveristesi Tıp Fakültesi, Kadın Hastalıkları Ve Doğum Anabilim Dalı, İzmir \\ ${ }^{3}$ Dokuz Eylül Üniveristesi Tıp Fakültesi, Patoloji Anabilim Dalı, İzmir
}

Dergiye Ulaşma Tarihi: 12.01.2019 Dergiye Kabul Tarihi: 26.07.2019 Doi: 10.5505/aot.2019.55376

\section{ÖZET}

GÍRİ̧̧ ve AMAÇ: Hem maspin hem de GLUT-1 ekspresyonu, endometrioid karsinom gibi birçok insan kanserlerini arttırdığı gösterilmiş olmasına rağmen, bunların uzun dönemde hastalığın prognozuyla ilgisi belirlenmemiştir.Çalışmamızın amacı, malign endometrial dokularda maspin ve GLUT-1'in aşırı ekspresyonunu araştırmak, endometrioid karsinoma gibi neoplastik dokularda progresyondaki rolünü değerlendirmek, sağkalımı öngörmedeki rolünü araştırmaktır.

YÖNTEM ve GEREÇLER: Çalışmaya endometrioid adenokarsinomlu 68 hasta ve iyi huylu endometrial dokuya sahip 68 hasta olmak üzere iki grup alındı. Maspin için immünohistokimyasal boyama nükleer ( çekirdek) olarak kabul edildi. Tümör dokularının ve normal endometriyal dokuların nükleer boyanması, hücre oranlarına göre şu şekilde skorlandı: negatif boyama <\% 25; pozitif boyama \% 25 -\% 100. GLUT-1 için boyama modeli membranöz olarak kabul edildi. Doku örneklerinde pozitif boyanmış tümör hücrelerinin yüzdesi yarı nicel olarak <\% 5 negatif boyama ve $\% 5$-\% 100 pozitif boyama ile belirlendi. Takip süresi 6 ila 60 ay arasında ve ortalama 53,8 ay idi.Birincil son noktalar tüm nedenlere bağl1 ölüm olarak belirlenmiştir.

BULGULAR: GLUT-1 ve Maspin'in immünohistokimyasal ekspresyonu endometrioid karsinomda belirgin bir şekilde daha yüksekti ( $\mathrm{p}<0.001)$. Sağkalım ile GLUT-1 arasında istatistiksel olarak belirgin bir fark yoktu.Maspin boyalı hastalarda sağkalım oranı düşük olmasına rağmen istatistiksel olarak anlamlı fark elde edilmedi $(\mathrm{p}=0,08)$. Maspin pozitif olan hastalarda prognoz çok daha kötüdür. GLUT-1, tümörlerin prognozunda ve metastazında önemli bir rol oynarken, aşırı eksprese maspinli dokularda aktivitesi gözlenmedi.

TARTIŞMA ve SONUÇ: GLUT-1, tümör ilerlemesi ve metastazı için önemli bir immün boyama belirteci iken, maspin endometrioid karsinomda prognostik bir parametre olarak daha etkili olduğu tespit edilmiştir.

Anahtar Kelimeler: endometrioid karsinom, GLUT-1 ve maspin, prognoz

\section{ABSTRACT}

INTRODUCTION: Although the expression of both maspin and GLUT-1 have been shown to increase in many human cancers such as endometrioid carcinoma, their long-term prognostic relevance has not yet been established. The aim of our study is to investigate the overexpression of maspin and GLUT-1 in malignant endometrial tissues, to evaluate its role in the neoplastic progression to an endometrioid carcinoma, to establish prognostic clinical parameters and to predict survival.

METHODS: The sample participants comprised of 68 patients with endometrioid adenocarcinoma and 68 patients with benign endometrial tissues. The immunostaining pattern for maspin was accepted as nuclear. Nuclear staining of tumoral tissues and normal endometrial tissues were scored according to cell ratios as follows: negative staining <25\%; positive staining 25\% - 100\%. The linear staining pattern for GLUT-1 was accepted as membranous. The percentage of positively stained tumor cells in the tissue samples were semiquantitatively determined with negative staining $<5 \%$ and positive staining $5 \%-100 \%$. The follow-up period ranged from 6 to 60 months with a mean of 53,8 months. Primary end points were determined as all-cause mortality.

RESULTS: The immunohistochemical expression of GLUT-1 and Maspin were significantly higher in 
endometrioid carcinoma $(\mathrm{p}<0.001)$. There was no statistically significant difference between survival and GLUT-1. Although the survival in patients with maspin staining was lower, statistical significance was not reached $(\mathrm{p}=0.08)$. In patients with positive maspin staining, the prognosis is much worse. While GLUT-1 plays an important role in the progression and metastasis of tumors, its activity was not observed in tissues with overexpressed maspin.

DISCUSSION and CONCLUSION: While GLUT-1 is an important immunostaining marker for tumor progression and metastasis, maspin has been identified to be more effective as a prognostic parameter in endometrioid carcinoma.

Keywords: endometrioid carcinoma, GLUT-1 and maspin, prognosis

\section{INTRODUCTION}

Endometrioid carcinomas are the most common malignancy of the female genital tract and are usually diagnosed and treated at early stages of the clinical progression, which enables good prognosis (1). However, advanced stages and recurrence of the disease are significantly associated with increased mortality, making endometrioid cancer the sixth most common cause of cancer-related deaths in the female population (2).

Two classes of genes - protooncogenes (e.g., ras) and tumor-suppressor genes (e.g., p53 ) - play key roles in cancer induction. These genes encode many proteins that control cell growth and proliferation; while mutations in these genes can contribute to the development of endometrioid cancer (3). Maspin (mammary serine protease inhibitor) is a tumour suppressor gene located on chromosome 18q21.3, which is a serpin family of protease inhibitors (4). It has been evinced to have tumour-suppressive functions through its inhibitory actions on motility, invasion and angiogenesis via the p53 gene (5). Cancer progresion has been observed to correlate with the downregulation of maspin expression that is present in normal tissues such as the breast, prostate and intestines. However, the expression of maspin was also oberved to paradoxically increase in several solid tumors (e.g. ovarian and pancratic) where it is not normally or minimally expressed in normal tissues (6,7). Several studies have identified maspin to be highly expressed in endometrioid cancer tissues compared with normal endometrium $(8,9)$, but the relationship between increased maspin and recurrence or survival has not yet been investigated.

Glucose transport protein (GLUT)-1 is a sodium-independent glucose transporter family member that is active in hypoxic conditions and is primarily found in erythrocytes, peripheral nerves, renal tubulus, lymph nodes and the blood-brain barrier $(10,11)$. Although Glut-1 expression is thought to be a high-potential marker of malignant transformation, the expression of endometrioid epithelial tissues in endometrioid cancer has not been clearly detected (12).

The aim of our study was to evaluate whether Glut-1 and Maspin are overexpressed in endometrioid cancers, and to establish the relationship between survival and recurrence in patients with this overexpression.

\section{MATERIALS and METHODS}

\section{Study Population}

This is a prospective cross-sectional study. All consecutive patients with endometrium carcinoma who had undergone surgery between 2011 and 2012 in the Department of Obstetrics and Gynecology (School of Medicine, 9 Eylül University, Izmir, Turkey) were considered eligible for the study. Our subjects comprised 68 patients with endometrioid adenocarcinoma and 68 patients with benign endometrial tissues (atrophic, proliferative and secretory endometrium). Endometrial hyperplasia was excluded because of the high ratio of maspin and GLUT-1 staining, especially in atypical form. All patients were surgically staged according to the International Federation of Gynecology and Obstetrics (FIGO) classification system of gynecological cancers. Tumors were grouped according to the World Health Organization (WHO) histopathologic grading criteria. Lymph node metastasis, positive-negative peritoneal cytology, lymphovascular space invasion (LVSI), recurrence, and the presence of distant metastases were recorded. The primary end point of the study was all-cause mortality. 


\section{Sample collection}

The best representative tumor specimen was taken from each case. Sections 2-3 microns in thickness were cut for immunohistochemical staining on paraffin blocks with Poly-L-lysinecoated, positively charged lamellae and stained with hematoxylin and eosin. Tissue samples taken on poly-L-lysine-positively charged slides were placed overnight at $50^{\circ} \mathrm{C}$ for deparaffinization. Immunohistochemical staining was performed automatically (VENTANA, Benchmark XT) using prediluted rabbit polyclonal concentrate antibody (Cell Marque, Santacruz Biotechnology, California, USA) for GLUT-1(Figure-1) and a mouse anti-human maspin(Figure-2) antibody (1:50; Santacruz Biotechnology, California, USA). Sections were incubated with primary antibodies for 30 minutes, then kept in $70 \%$, $80 \%, 95 \%$ alcohol and absolute alcohol for 2 minutes, consecutively. After drying in air, sections were kept in xyloid for 15 minutes and enclosed with entellan.

\section{Immunohistochemistry assessment}

The whole sections were scanned at 4X, 10X, 20X and 40X magnifications (NIKON Eclipse E600, Japan). The ratio of nuclear-positive stained cells was calculated by counting 1000 cells per tumor at $40 \mathrm{X}$ magnification. The immunostaining pattern for maspin was accepted as nuclear. Cytoplasmic and/or membranous staining, i.e. anything other than nuclear staining, was considered a negative result. Nuclear staining of tumoral tissues and normal endometrial tissues were scored according to cell ratios as follows: negative staining <25\%; positive staining 25\% - 100\%. The linear staining pattern for GLUT-1 was accepted as membranous. The percentage of positively stained tumor cells from the samples were semi- quantitatively determined, with negative staining $<5 \%$ and positive staining $5 \%-100 \%$.

\section{Statistical Analysis}

Statistical analysis was performed using the SPSS for Windows software, version 15 (Chicago, Illinois). Continuous variables are expressed as mean + standard deviation, whereas categorical variables are displayed as numbers and percentages. Student's t-tests and nonparametric Mann-Whitney $U$ tests were used to determine the differences between mean values for normally and nonnormally distributed variables, respectively. Categorical variables were reported as percentages and were analyzed by either the chi-square or Fisher exact test, as appropriate. All tests were 2 sided, and a significance level of 5\% was used.

\section{RESULTS}

The clinical staging of 68 patients revealed 40 patients with FIGO stage I, 19 with FIGO stage II, and 9 with FIGO stage III carcinomas. For statistical analyses, stages I and II were considered low while stage III was considered high. The clinicopathologic characteristics of patients are presented in Table 1 . The mean follow-up was 53,8 months (range, 6 to 60 months). In 6 of the patients, positive peritoneal cytology was detected, while in 62 patients, peritoneal cytology was negative. Fifty-eight of the patients had no recurrence; while 10 of the patients developed local recurrence.

Expression patterns of maspin and GLUT-1 in endometrium carcinoma are shown in Table 2. Although the increase in prevalence of nuclear staining of Maspin in advanced stages was statistically significant, there were no significant differences of maspin staining in myometrial invasion, peritoneal cytology, LVSI nor lymph node involvement. On the other hand, GLUT-1 expression was higher in patients with LVSI, and myometrial invasion of endometrium carcinoma.

Maspin and GLUT- 1 expression were found to be higher in endometrial cancers when compared to the control group $(p<0.001)$. Although the 5-year survival in patients with maspin staining was lower, statistical significance was not reached $(\mathrm{p}=0.08)$. Meanwhile, GLUT-1 expresion was not associated with the 5-year survival in patients with endometrium carcinoma. 
Table I. The clinicopathologic features of endometrium carcinoma

\begin{tabular}{|c|c|}
\hline Clinical Characteristics & Number of cases \\
\hline $\begin{array}{l}\text { FIGO grade } \\
1 \\
2 \\
3\end{array}$ & $\begin{array}{l}40(58,8) \\
19(27,9) \\
9(13,2)\end{array}$ \\
\hline $\begin{array}{l}\text { Histological grade } \\
1 \\
2 \\
3\end{array}$ & $\begin{array}{l}50(73,5) \\
16(23,5) \\
2(3)\end{array}$ \\
\hline $\begin{array}{l}\text { Lymph node } \\
\text { involvement } \\
\text { Absent } \\
\text { Present }\end{array}$ & $\begin{array}{l}55(80,9) \\
13(19,1)\end{array}$ \\
\hline $\begin{array}{l}\text { LVI } \\
\text { None } \\
\text { Positive } \\
\end{array}$ & $\begin{array}{l}40(\% 58,8) \\
28(\% 41,2)\end{array}$ \\
\hline $\begin{array}{l}\text { Peritoneal cytology } \\
\text { Negative } \\
\text { Positive }\end{array}$ & $\begin{array}{l}62(\% 91,2) \\
6(\% 8,8)\end{array}$ \\
\hline $\begin{array}{l}\text { Myometrial invasion } \\
\text { IA } \\
\text { IB } \\
\end{array}$ & $\begin{array}{l}25(36,8) \\
43(63,2) \\
\end{array}$ \\
\hline
\end{tabular}

FIGO, International Federation of Gynecology and Obstetrics. LVI, lymphovascular invasion IA: $\leq \% 50$ myometrial thickness IB: > \%50 myometrial thickness

\section{DISCUSSION}

Previous studies have shown increased expression of maspin and GLUT-1 genes in endometrial cancers, especially in several solid tumors, whereas it is not at all or minimally expressed in normal tissues $(6,13,14)$. Longterm follow-up studies have not been performed. The increase in maspin and GLUT1 expression in patients with endometrial cancer has been observed $(8,15)$. Our study demostrated that there is upregulated expression of maspin and GLUT-1 in endometrial adenocarcinoma, with an associated worse 5-year prognosis in those with maspin expression.

Malignant tumors synergize with hypoxic conditions through various molecules. Hypoxia induces the neovascularization and glycolytic activity associated with invasiveness and metastatic capacity; numerous studies have shown the presence of distinct hypoxic sites in multiple tumors (16).

Malignant tumor development is an energy-dependent process that is supported by an increase in glucose metabolism, which results in the increased expression of glucose transport proteins on the cell membrane. GLUT-1 mediates glucose uptake and thus facilitates anaerobic glycolysis. This protein is essentially undetectable in normal epithelium and benign tumors, but expression in various tumors, including in cervix, lung, stomach and colorectal cancers, has been reported to be associated with poor prognosis (17). Mendez et al. observed an overexpression of GLUT-1 in cervical squamous cell carcinoma. It was also determined that the staining intensity was significantly increased in all grades of carcinomas compared to dysplasia and normal epithelium (13). In an immunohistochemical study of glucose transporters (GLUT-1, GLUT-3 and GLUT-4) in 154 patients with epithelial ovarian carcinoma, GLUT-1 and GLUT-4 expressions were reported to correlate with disease progression (14). FIGO staging, total abdominal hysterectomy, bilateral salpingo-oophorectomy and pelvic lymph node dissection operations were performed in 100 cases of endometrioid type adenocarcinoma. An increase in GLUT-1 expression was observed with the progression of the disease stage (18). In our study, there was no statistically significant correlation between GLUT-1 expression and tumor stage ( $\mathrm{p}=$ 0.334 ); this may be due to a small case number of advanced stages included in the study. A series of more homogeneous stage groups may yield different results.

Maspin, a protease inhibitor, has also been described as a type II tumor suppressor gene (19), and has been shown to localize in either or both the nucleus and/or the cytoplasm, varying with the type of malignancy (20-22). $\mathrm{Li}$ and colleagues investigated 34 patients with endometrioid endometrium adenocarcinoma (FIGO stage I and III) and 28 normal endometrium tissues, which showed higher maspin expression in stages I and III tumors compared to normal endometrium ( $\mathrm{p}<0.01)$. However, the same relationship cannot be shown between stages I and stage III (8). We did not find statistical significance between maspin expression and lymph node metastasis in our study. However, 
as the tumor progressed, the expression of maspin significantly increased $(p=0.019)$.

Prognosis is an important marker of survival, and publications have different results. In a study of breast cancer cases conducted in 2007, it was shown that survival was statistically lower with maspin expression in univariate analysis (23). In a study evaluating immunohistochemical maspin expression in invasive breast carcinoma cases, it has been reported that maspin overexpression is associated with increased risk of death without involvement of the lymph node (24). In other study, there was no correlation between maspin expression and survival in patients with colorectal cancer (21). In addition, there was a statistically nonsignificant difference between 5 -year survival and maspin over-expression $(\mathrm{p}=0.08)$. This value was thought to be significant in the series with larger patient numbers. The main limitation of the present study is the relatively small sample size; therefore, our data should be confirmed in future studies. These are also observational data from one institution.

In conclusion, GLUT-1 and Maspin immunohistochemical over-expressions were significantly higher in endometrial carcinoma. Although there was no statistically significant difference between survival and GLUT-1, maspin's over-expression effect on survival could be regarded as borderline significant. In patients with positive maspin staining, both prognosis and survival are determined to be worse. On the other hand, GLUT-1 plays an important role in the progression and metastasis of the tumor; however, its activity was not observed in those with maspin over expression.

\section{Conflict of interest:None}

\section{REFERENCES}

1. Rose PG. Endometrioid carcinoma. N Engl J Med 1996; 335: 640-649.

2. Siegel RL, Miller KD, Jemal A. Cancer Statistics, 2017. CA Cancer J Clin. 2017 Jan;67(1):7-30

3. Iurlaro $R$, León-Annicchiarico $C L$, Muñoz-Pinedo C. Regulation of cancer metabolism by oncogenes and tumor suppressors. Methods Enzymol. 2014;542:59-80.

4. Zou Z, Anisowicz A, Hendrix MJ, et al. Maspin, a serpin with tumor-suppressing activity in human mammary epithelial cells. Science. 1994 Jan 28;263(5146):526-9.
5. Zou Z, Gao C, Nagaich AK et al. p53 regulates the expression of the tumor suppressor gene maspin. $J$ Biol Chem 2000; 275: 6051-4.

6. Sood AK, Fletcher MS, Gruman LM, et al: The paradoxical expression of maspin in ovarian carcinoma. Clin Cancer Res 8: 2924-2932, 2002.

7. Maass N, Hojo T, Ueding M, et al. Expression of the tumor suppressor gene Maspin in human pancreatic cancers. Clin Cancer Res. 2001 Apr;7(4):812-7.

8. Li HW, Leung SW, Chan CS, et al. Expression of maspin in endometrioid adenocarcinoma of endometrium. Oncol Rep. 2007 Feb;17(2):393-8.

9. Blandamura S, Alessandrini L, Saccardi C, et al. Maspin expression, subcellular localization and clinicopathological correlation in endometrial hyperplasia and endometrial adenocarcinoma. Histol Histopathol. 2014 Jun;29(6):777-83.

10. Younes M, Lechago LV, Somoano JR, et al. Wide expression of the human erythrocyte glucose transporter Glut1 in human cancers. Cancer Res. 1996 Mar 1;56(5):1164-7.

11. Froehner SC, Davies A, Baldwin SA, et al. The blood-nerve barrier is rich in glucose transporter. $\mathrm{J}$ Neurocytol. 1988 Apr;17(2):173-8.

12. Noguchi Y, Saito A, Miyagi Y, et al. Suppression of facilitative glucose transporter 1 mRNA can suppress tumor growth. Cancer Lett. 2000 Jun 30;154(2):175-82.

13. Mendez LE, Manci N, Cantuaria $G$, et al. Expression of glucose transporter-1 in cervical cancer and its precursors. Gynecol Oncol. 2002 Aug;86(2):138-43.

14. Tsukioka $M$, Matsumoto $Y$, Noriyuki $M$, et al. Expression of glucose transporters in epithelial ovarian carcinoma: correlation with clinical characteristics and tumor angiogenesis. Oncol Rep. 2007 Aug;18(2):361-7.

15. Canpolat $T$, Ersöz $C$, Uğuz $A$, et al. GLUT-1 Expression in Proliferative Endometrium, Endometrial Hyperplasia, Endometrial Adenocarcinoma and the Relationship Between GLUT-1 Expression and Prognostic Parameters in Endometrial Adenocarcinoma. Turk Patoloji Derg. 2016;32(3):141-7.

16. Cooper R, Sarioğlu S, Sökmen S, et al. Glucose transporter-1 (GLUT-1): a potential marker of prognosis in rectal carcinoma? Br J Cancer. 2003 Sep 1;89(5):870-6.

17. Nishioka T, Oda Y, Seino Y, et al. Distribution of the glucose transporters in human brain tumors. Cancer Res. 1992 Jul 15;52(14):3972-9

18. Ozbudak IH, Karaveli S, Simsek $\mathrm{T}$, et al. Neoangiogenesis and expression of hypoxiainducible factor 1alpha, vascular endothelial growth factor, and glucose transporter-1 in endometrioid type endometrium adenocarcinomas. Gynecol Oncol. 2008 Mar;108(3):603-8.

19. Sheng $\mathrm{S}$, Truong $\mathrm{B}$, Fredrickson $\mathrm{D}$, et al. Tissuetype plasminogen activator is a target of the tumor suppressor gene maspin. Proc Natl Acad Sci USA 1998; 95: 499-504.

20. Mhawech-Fauceglia $P$, Dulguerov $P$, Beck A, et al. Value of ezrin, maspin and $\mathrm{nm} 23-\mathrm{H} 1$ protein expressions in predicting outcome of patients with head and neck squamous-cell carcinoma treated 
with radical radiotherapy. J Clin Pathol. 2007 Feb;60(2):185-9.

21. Zheng $H$, Tsuneyama $K$, Cheng $C$, et al. Maspin expression was involved in colorectal adenomaadenocarcinoma sequence and liver metastasis of tumors. Anticancer Res. 2007 Jan-Feb;27(1A):25965.

22. Nakagawa M, Katakura H, Adachi M, et al. Maspin expression and its clinical significance in non-small cell lung cancer. Ann Surg Oncol. 2006 Nov;13(11):1517-23.

23. Tsoli E, Tsantoulis PK, Papalambros A, et al. Simultaneous evaluation of maspin and CXCR4 in patients with breast cancer. J Clin Pathol. 2007 Mar;60(3):261-6.

24. Lee MJ, Suh CH, Li ZH. Clinicopathological significance of maspin expression in breast cancer. J Korean Med Sci. 2006 Apr;21(2):309-14 